\title{
A Partial Albino Hatchling Northern Ring-necked Snake, Diadophis punctatus edwardsii, from Big Tancook Island, Mahone Bay, Lunenburg County, Nova Scotia, Canada
}

\author{
John Gilhen ${ }^{1}$, Graham Caswell, Carrie Drake, Mary MacDonald, and Heather McKinnon- \\ RAMSHAW
}

Nova Scotia Museum of Natural History, 1747 Summer Street, Halifax, Nova Scotia B3H 3A6 Canada.

${ }^{1}$ Corresponding author (email: gilhenja@gov.ns.ca)

Gilhen, John, Graham Caswell, Carrie Drake, Mary MacDonald, and Heather McKinnon-Ramshaw. 2012. A partial albino hatchling Northern Ring-necked Snake, Diadophis punctatus edwardsii, from Big Tancook Island, Mahone Bay, Lunenburg County, Nova Scotia, Canada. Canadian Field-Naturalist 126(4): 336-339.

On 10 June 2012 a sample of seven gravid female Northern Ring-necked Snakes (Diadophis punctatus edwardsii), from Big Tancook Island, Lunenburg County, Nova Scotia, was selected for a seasonal live display at the Nova Scotia Museum of Natural History in Halifax. A total of 13 eggs was removed from the display in late June 2012 and incubated for public viewing. The eggs began hatching on 22 August 2012. One of the hatchlings was partial albino (with zanthophores or amelanistic). This is the first record of an albinistic Northern Ring-necked Snake in Nova Scotia.

Key Words: partial albino, zanthophore, amelanistic, hatchling, Northern Ring-necked Snake, Diadophis punctatus edwardsii, Big Tancook Island, Nova Scotia.

We collected seven gravid female Northern Ringnecked Snakes (Diadophis punctatus edwardsii) from among approximately 40 adults observed on Big Tancook Island, Mahone Bay, Lunenburg County, Nova Scotia $\left(44^{\circ} 27^{\prime} 00^{\prime \prime N}, 64^{\circ} 10^{\prime} 00^{\prime \prime W}\right.$ ) (Figure 1) on 10 June 2012 for a live display in the Netukulimk Gallery of the Nova Scotia Museum of Natural History in Halifax over the summer. The females (three slate grey and four brown morphs) were found under loose slate, boards, and other debris in tall grass in a clear-cut area about $100 \mathrm{~m}$ from the sea shore. Big Tancook Island is a drumlin 4 kilometers long and $1.6 \mathrm{~km}$ wide.

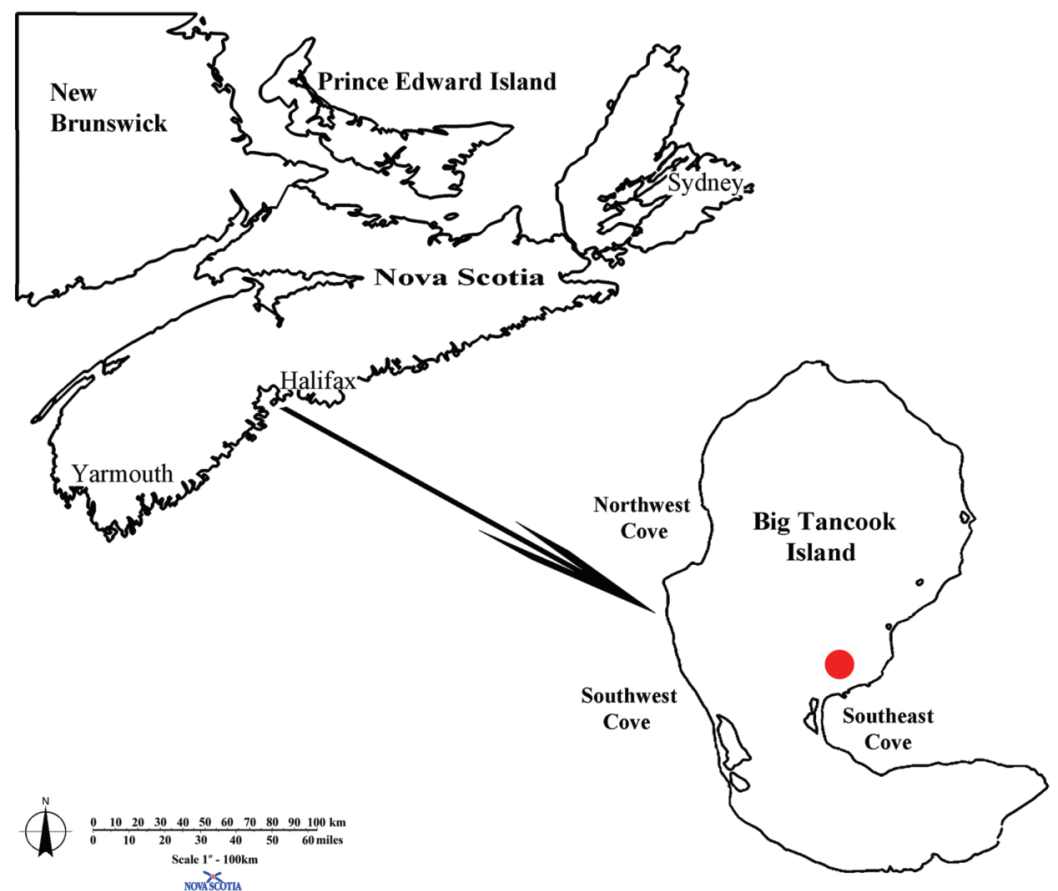

FIgURE 1. Map of Big Tancook Island, Mahone Bay, Lunenburg County, Nova Scotia. Photo by Roger Lloyd. 


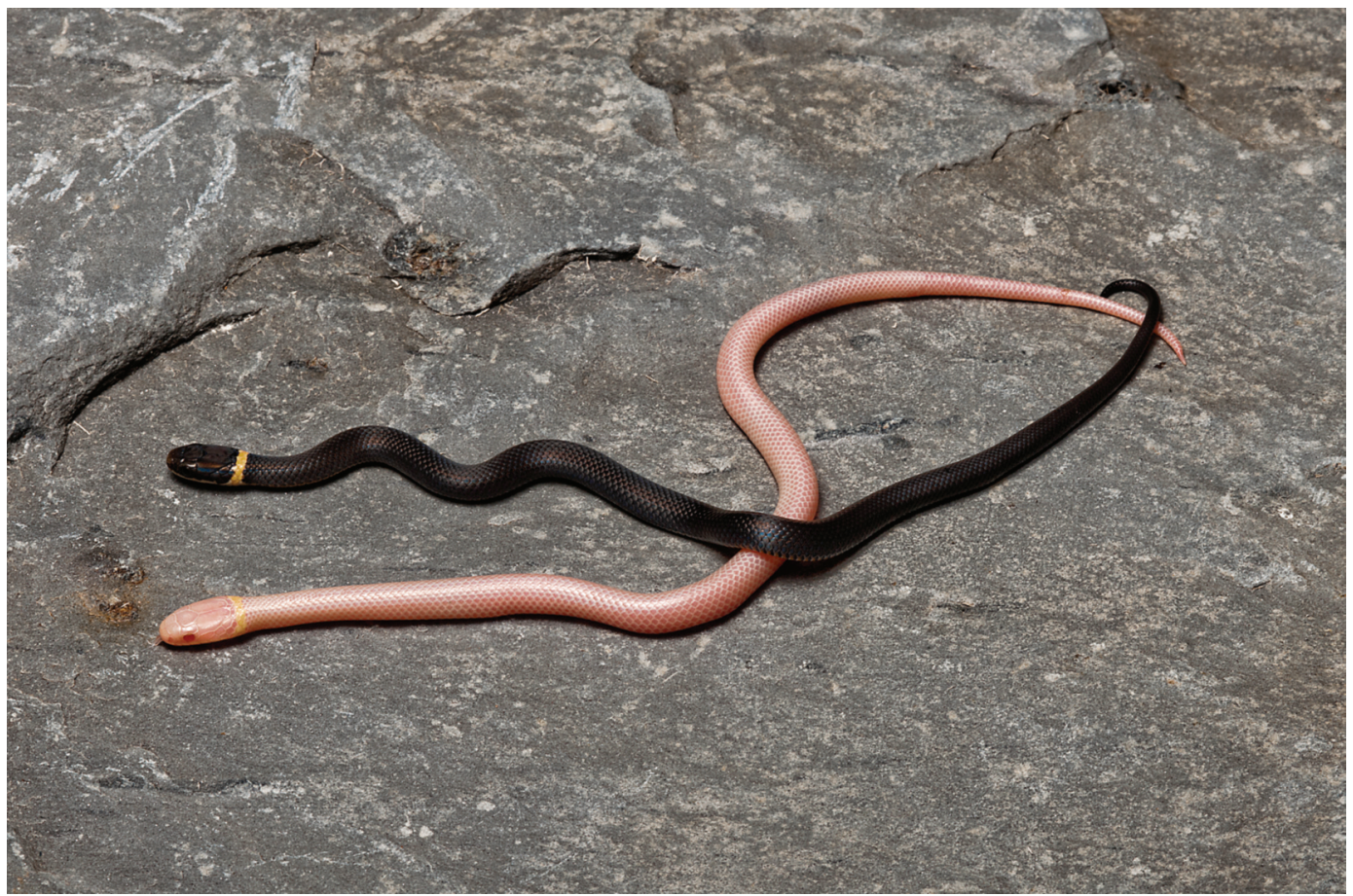

FIGURE 2. Dorsal view of an albinistic and a normal Northern Ring-necked Snake, Diadophis punctatus edwardsii, both hatched on 22 August 2012 from eggs laid by gravid females that were collected on 10 June 2012 from Big Tancook Island, Mahone Bay, Lunenburg County, Nova Scotia. Photo by Roger Lloyd.

A total of 13 eggs were laid by the females in late June 2012. The eggs were removed from the display and incubated so that the public could observe them hatching. One of the hatchlings (see cover illustration) was comparable to the partial albino (with zanthophores or yellow pigment) described by Drykacz (1981). It was also amelanistic in that it completely lacked black pigment, which is characteristic of the ground colour of this subspecies in Nova Scotia (Gilhen, 1970).

This hatchling, approximately $12 \mathrm{~cm}$ total length and 1.2 grams in weight, had pink eyes and a white tongue. The dorsal colour was pinkish-white with a pale yellow neck band. The neck band was bordered anterior and posteriorly by a narrow grey translucent band (Figure 2). The underside was yellowish-orange (Figure 3), paler than that of normal hatchlings.

A partial leucistic adult male Northern Ring-necked Snake (leucistic with erythrophores) approximately $30 \mathrm{~cm}$ in total length was found under a large piece of quartzite in a boulder field at Geizer Hill, west of peninsular Halifax City, Nova Scotia $\left(44^{\circ} 39^{\prime} 03^{\prime \prime N}\right.$, 63³9'28"W), on 28 June 1997 (Gilhen 1999) (Figure 4). This snake lacked black pigment except for the eyes, which were black. Above, the snake was greyishwhite on the trunk and pinkish-white on the tail. The skin between the scales was dull white. The major dif- ferences between that specimen and the albino hatchling described above is that the albino hatchling had pink eyes and a white tongue (see cover illustration) and the leucistic individual had black pigmented eyes and red tongue (Figure 4). The head of the hatchling was pinkish-white and the head of the adult male was orange brown. Both had a pale yellow band round the neck with a greyish translucent border above and below. The underside of the hatchling was yellowishorange while the adult male was darker orange. Based on these differences, we propose that this hatchling is the first record in Nova Scotia of a partial albino Northern Ring-necked Snake with zanthophores.

\section{Discussion}

In Nova Scotia, reports of albino, leucistic, and amelanistic amphibians and reptiles have increased in recent decades. Such anomalies happen rarely in nature. However, in Nova Scotia these phenomena are believed to be the result of inbreeding in isolated, disturbed and fragmented habitats (Russell et al 2012).

Nova Scotia is a narrow and elongate province which juts out into the Atlantic Ocean. With the exception of sea turtles and species introduced onto Newfoundland, it represents the northeastern limit for amphibians and reptiles. The entire landscape is almost completely sur- 


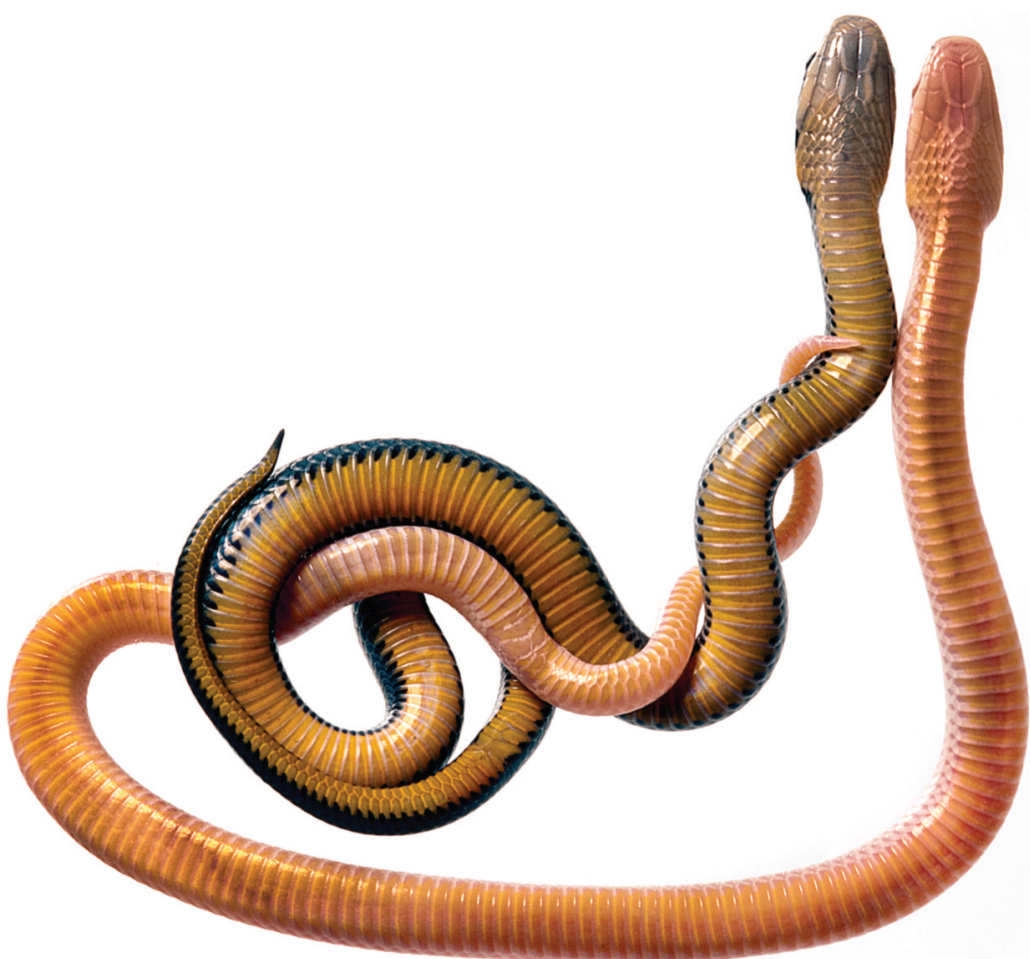

FIGURE 3. Ventral view of an albinistic and a normal Northern Ring-necked Snake, Diadophis punctatus edwardsii, both hatched on 22 August 2012 from eggs laid by gravid females that were collected on 10 June 2012 from Big Tancook Island, Mahone Bay, Lunenburg County, Nova Scotia. Photo by Roger Lloyd.

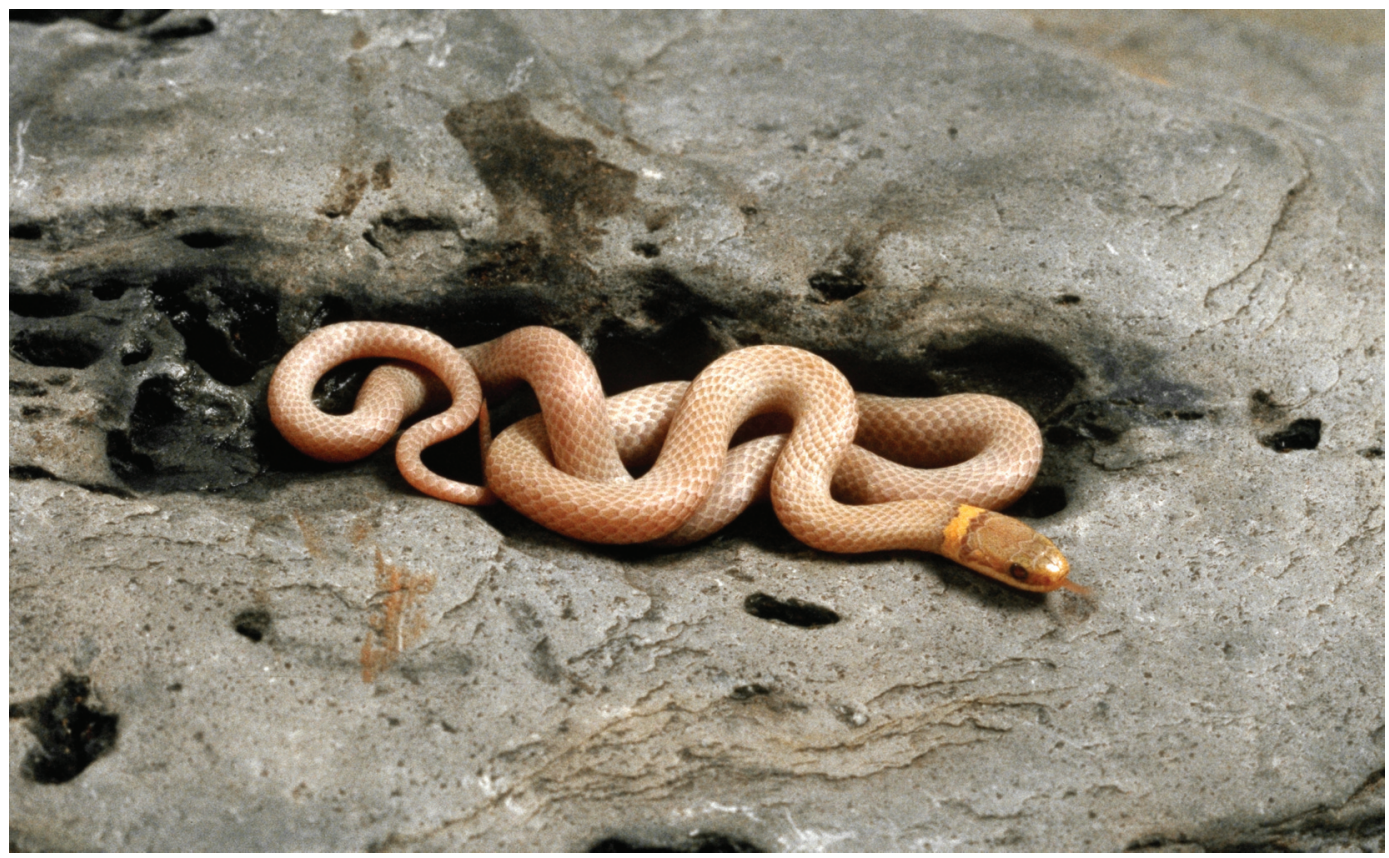

FIGURE 4. Dorsal view of an adult male leucistic Northern Ring-necked Snake, Diadophis punctatus edwardsii, from Geizer Hill, west of peninsular Halifax, Halifax County, Nova Scotia, on 28 June 1997. Photo by Roger Lloyd and Richard Plander. 
rounded by the sea, and the present native herpetofauna has been isolated here for thousands of years (Bleakney 1958, Cook 1967 and Gilhen 1984). The province is also characterized by a varied geology, topography, and climate, which can limit the distributional gene flow for some species, such as the Northern Ring-necked Snake (Gilhen, 1984).

The Atlantic coast of Nova Scotia in many areas is clustered with islands inhabited by amphibians and reptiles, particularly salamanders and snakes, separated from the mainland for centuries and in some cases thousands of years. Major highways follow the coast and often separate the amphibians and reptiles inhabiting the numerous coastal peninsulas and further inhibit gene flow. In recent years, urbanization of these peninsulas has created an "island" effect, which further divides amphibian and reptile populations.

This carving up of the landscape makes it more likely that individuals carrying a recessive gene for the albino, leucistic and amelanistic conditions will encounter and mate with individuals of similar genotype in these small, isolated habitats. Consequently, in the future, we expect more frequent reports of amphibians and reptiles in Nova Scotia that manifest these aberrant conditions.

\section{Acknowledgements}

The authors are grateful to Roger Lloyd for producing the cover image, and, also Figures 1, 2, and 3. Roger Lloyd and Richard Plander worked together on Figure 4 . The continued professional care of seasonal live displays at the Nova Scotia Museum of Natural History, Halifax, in particular, professional help main- taining and feeding the partial albino hatchling Northern Ring-necked Snake (which is eating and growing at this time in the Nature Lab) is done by the naturalist/interpreters. Andrew Hebda, Curator of Zoology, made useful comments on the draft manuscript. Katherine Ogden, Assistant Curator, was very helpful during the preparation of the manuscript.

\section{Literature Cited}

Bleakney, J. S. 1958. A zoogeographical study of the amphibians and reptiles of eastern Canada. National Museums of Canada. Bulletin 155: 1-119.

Cook, F. R. 1967. An analysis of the herpetofauna of Prince Edward Island. National Museums of Canada Bulletin 212. 60 pages.

Dyrkacz, S. 1981. Recent instances of albinism in North American amphibians and reptiles. Society for the study of amphibians and reptiles. Herpetological Circular Number 11 .

Gilhen, J. 1970. An unusual Nova Scotian population of the Northern Ringneck Snake, Diadophis punctatus edwardsi. Occassional Paper No. 9, Science Series No. 6. Nova Scotia Museum, Halifax, Nova Scotia. 21 pages.

Gilhen, J. 1984. Amphibians and Reptiles of Nova Scotia. Nova Scotia Museum. Halifax, Nova Scotia.

Gilhen, J. 1999. First record of a partial leucistic Northern Ring-necked Snake, Diadophis punctatus edwardsi, in Nova Scotia. Canadian Field-Naturalist 113: 282-284.

Russell, R. W., W. Beslin, M. Hudak, A. Ogunbiyi, A. Withrow, and J. Gilhen. 2011. A second amelanistic Eastern Red-backed Salamander, Plethodon cinereus, from Nova Scotia, Canada. Canadian Field-Naturalist 125: 359-362.

Received 27 November 2012

Accepted 3 December 2012 